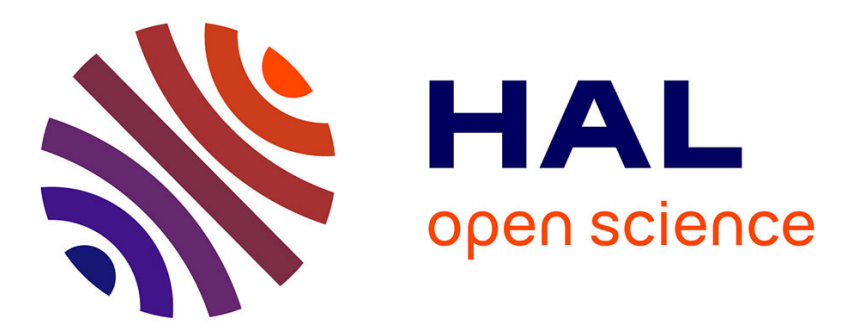

\title{
Antonio Ioris, 2018, Agribusiness and the Neoliberal Food System in Brazil: frontiers and fissures of agro-neoliberalism
}

\author{
Paulo Niederle
}

\section{- To cite this version:}

Paulo Niederle. Antonio Ioris, 2018, Agribusiness and the Neoliberal Food System in Brazil: frontiers and fissures of agro-neoliberalism: New York, Routledge, 218 p. Review of Agricultural, Food and Environmental Studies, 2019, 100 (1-4), pp.121-124. 10.1007/s41130-019-00084-w . hal-03114863

\section{HAL Id: hal-03114863 \\ https://hal.science/hal-03114863}

Submitted on 19 Jan 2021

HAL is a multi-disciplinary open access archive for the deposit and dissemination of scientific research documents, whether they are published or not. The documents may come from teaching and research institutions in France or abroad, or from public or private research centers.
L'archive ouverte pluridisciplinaire HAL, est destinée au dépôt et à la diffusion de documents scientifiques de niveau recherche, publiés ou non, émanant des établissements d'enseignement et de recherche français ou étrangers, des laboratoires publics ou privés. 


\title{
Antonio loris, 2018, Agribusiness and the Neoliberal Food System in Brazil: frontiers and fissures of agro-neoliberalism
}

\author{
New York, Routledge, $218 p$
}

\section{Paulo Niederle ${ }^{1}$}

Received: 21 December 2018 / Accepted: 7 January 2019 / Published online: 14 January 2019 (C) L'Institut National de la Recherche Agronomique (INRA) 2019

The leading narrative about the power of the Brazilian agribusiness is maintained by a vaunt image of individual entrepreneurs promoting modern technological innovations and bringing the "development" to the most recondite regions of the country. This book demonstrates the fallacy of this narrative through three main evidences. First, the fact that the "agro-neoliberalism" is largely anchored in the spoliation of cheap labor and natural resources. Second, the confirmation that these activities are only economically viable because of strong State support. Third, the recognition that their socioenvironmental costs questions the virtuosity of this model of development.

The first evidence is generally associated with the expansion of agricultural commodity production, mainly of soybeans. In the last two decades, Brazil has taken advantage of the commodity prices "boom" to consolidate itself as one of the world's leaders in this market. In 2017, although Brazil was not yet the global leadership in soybean production (114 kilo metric tons (KMT), or 31\%, against $33 \%$ of the USA), this country was already the biggest global exporter (68 KMT, or $42.5 \%$, against $39 \%$ of the USA). The main responsible for that is the Chinese demand. While, in 1997, Chinese purchases accounted for only $11 \%$ (0.61 billion Brazilian real) of soybean total value exported by Brazil, in 2015, it already represented 57\% (16 billion Brazilian real). In that period, soybean became the most significant Brazilian export product, representing, in terms of value, around $20 \%$ of all exported products and half of the agribusiness sector exports. This data corroborates a trajectory of "regressive specialization," since "the Brazilian economy has faced progressive deindustrialisation, increased dependence on foreign investments and rising imports of intermediate inputs and capital goods" (p. 61).

In the province of Mato Grosso, Brazilian leader in soybean production with 29 KMT ( $28 \%$ of the national amount), and where 106 of 140 municipalities produce this

Paulo Niederle

pauloniederle@gmail.com

1 Federal University of Rio Grande do Sul, Porto Alegre, Brazil 
grain, soybean cropping area grew from 48.7 to 54.8 million hectares between 2006 and 2017. Most part of this process was concentrated in largest specialized farms, including those now controlled by foreign investors, transnational corporations, and financial funds. This process led Mato Grosso to the top of the list of the most important areas of global land grabbing, a phenomenon defined by the expansion of a vulture capitalism that aims to access and control land, and, more widely, water and natural resources. Whereas this is a widely discussed event in agrarian studies, what is new in this book is the empirical evidences it provides us to understand how this process operates in the daily life of the rural communities, including analysis of violent and illegal practices used to expel smallholders from their lands.

From the example of soybean expansion ("soyfication"), this book also demonstrates the promiscuous relationship between private and state actors. This second main evidence questioning the narrative of the "successful agribusiness" is the focus of the Chapter 4, The Rent of Agribusiness, which demonstrates how different public policy instruments enable the high profitability of private investments in a low value-added sector. These instruments involve highly subsidized credit for commodity production, flexibilisation of labor and environmental laws, tax exemptions for commodities export, currency devaluation, and the recurrent forgiveness of large farms' debts with the State, which is one of the most direct mechanisms of public resources privatization. As the author demonstrates, these instruments ensure that the Brazilian "titanic agriculture" survives the crises of commodity devaluation in international markets and, doing so, avoid the iceberg of an "agriculture-titanic."

From this first evidence, the book delves into an intricate discussion about the characterization of the neoliberalism or, as the author prefers to define, "agro-neoliberalism," this "politico-ecological project that has deepened and intensified the multiple mechanisms of labour and nature exploitation required to maximize exchange values" (p. 53). According to Ioris, "the central promoter of agro-neoliberalism, despite all rhetoric of free market rationality, continues to be the national state, but often operating through new partnerships with the private sector and through multilateral organization" (p. 52). This conclusion ratifies the claims of other well-known agri-food market analysts (such as Alessandro Bonanno, Steven Wolf, Lawrence Bush, and Gerardo Otero), who argue that neoliberalism is, above all, a fabulous and ideological project, which at the same time pleas for free market, demands continuous State intervention to guarantee private gains.

This discussion brings up an issue regarding the categorization of the regime of accumulation-regulation that prevailed in Brazil during the last two decades of leftwing governments, which at least discursively, criticized neoliberal policies. At the end of the 1990s, the neoliberal narrative faced a huge crisis of legitimation in several countries due to all social problems produced by market liberalization and welfare state bankruptcy. In some cases, such as in Brazil and most part of Latin America, this crisis opened the window of opportunity the center-left political coalitions needed to conquer the State (or, more precisely, the government). However, in order to ensure political governability, these coalitions maintained macroeconomic policies that were, in a great measure, aligned with the previous neoliberal agenda. As a result, they produced a hybrid strategy combining liberal and developmental policy goals and instruments, leading some analysts, in their efforts to define the Brazilian development model in this period, to formulate schizophrenic concepts such as "liberal-neodevelopmentalism." 
In spite of conceptual divergences, analysts state that global commodity markets were essential to support this model of development. On the one hand, public policies legitimized and encouraged the agro-neoliberal regime of accumulation in based on the export of commodities and, on the other hand, used its dividends to expand investments and social policies that are more typically found in neo-developmental States. It means that, for two decades, Brazilian center-left governments tried to conciliate antagonistic interests by promoting a game in which, supposedly, everybody could win. Nevertheless, over time, the public policies' contradictions, as well as the winners and losers, have become more and more evident. For instance, while large farms, agribusiness transnational companies, and financial funds have benefited from the land grabbing, the resultant overvaluation of land prices increased opportunity costs for smallholders, spoliation of natural resources, and socio-environmental conflicts.

The third set of evidences presented by this book focuses precisely on the main social effects of this model of "accumulation by dispossession": the expulsion of smallholders from their lands, concentration of wealth and power, and exponential increase of socio-economic inequalities. In order to interpret these processes, the book proposes a dialogue among political geography, political ecology, and assemblage theory. This dialogue is the basis of a multi-scale approach that seeks to connect the global dynamics of agro-neoliberalism with changes taking place in the social actors' lifeworld, including subjective perceptions of those most directly affected ones by these dynamics. In this sense, the last chapters of the book present results from a detailed field research carried out in some of the main Brazilian "agribusiness cities," such as Lucas do Rio Verde, Sorriso, and Sinop. Founded by "gaucho" immigrants (southern farmers of European ethnic origin who migrated in search of new areas for grain production), these cities became the most visible expression of the two faces of the "development" brought by the expansion of the agricultural frontier: wealth and poverty.

With the aim of demonstrating it, the author went into the most remote rural areas to understand the effects of the expansion of soybeans on the socio-ecological dynamics of the territories, particularly taking into account the disintegration of the modes of production and life of smallholders and traditional communities. Here, we can again see illegal and violent means used by agribusiness agents to force these farmers to leave their lands, which leads the author to conclude that "the production of new places combined elements of a hypermodern economic boom with pre-capitalist practices" ( $p$. 141). Subsequently, Ioris explores the production of inequality in urban spaces. On the one side, he reveals modern material infrastructures built to make agribusiness feasible, such as storage and distribution centers, banks, machinery, and agricultural equipment shops, as well as the comfortable residences of agricultural entrepreneurs (who generally do not live on their farms). On the other side, he highlights the presence of the homeless and peri-urban favelas formed by smallholders families who were expelled from their land or migrated from other regions searching for the promises of development of the agribusiness cities.

Since the beginning of the 2000s, these contradictions and inequalities have been attenuated by the broad dissemination of social policies to face poverty and hunger. However, this situation has become unsustainable since the deterioration of the global financial crisis, which implied the collapse of commodity prices, impacting the export of primary goods, the expansion of interest rates, the augmentation of inflation and 
production costs, and the reduction of public and private investments. Hence, to mitigate the effects of the global crisis and counter internal political conflicts, centerleft governments began to adopt anti-cyclical policies, mainly increasing subsided credit to consumption. Besides the State indebtedness, these policies soon revealed insufficient to maintain the levels of profitability required by the agribusiness investors, who turned against the government to become one of the main supporters of the political movement that, in 2016, deposed President Dilma Roussef.

Following the collapse of the center-left coalition, the neoliberal narrative gained new strength, legitimizing measures of fiscal adjustment and reduction of public expenditures in some sectors - but, the continuity of benefits for the agri-food exporter sector, including new debt forgiveness for the biggest farms. In 2018, the new scenario opened by the electoral success of an extreme right coalition not only points to a deepening of this model, but also adds to this a new authoritarian and conservative character. Since they are so recent, these movements have not been analyzed in this book. Even though, they bring up a question the author started to interpret, yet he did not provide a definitive answer: how to interpret the different varieties of (agro) neoliberalism produced in different historical and spatial contexts? According to the author, "neoliberalism is a variegated, geographically uneven and path-dependent process" (p. 49). Besides, offering a very interesting synthesis of the emergence and consolidation of a variety of agro-neoliberalism in the last decades, this book motivates a research agenda on this new variety of neoliberalism that is being born from the current conservative and authoritarian turn in Brazil and elsewhere.

In short, Ioris's book analyses one of the main faces of the agrarian development in Brazil. It does so from an innovative theoretical framework, which seeks to combine elements of a political economy of globalization, with sociological approaches centered on social actors' subjectivities. In addition, it presents an impressive wealth of data not only on the dynamics of the global commodity markets, but how they have impacted the lives of rural communities in those regions where agribusiness expansion has been more intense. This is the result of the empirical research that Ioris has been conducting for several years in some of the main agribusiness cities in Brazil. It is important to note, however, that the social processes explored in this book are only part of history. In our view, both the theoretical framework adopted and the data presented would have difficulties in answering questions about the emergence of new rural development dynamics, which are anchored in food production and consumption practices guided by other social values, such as environmental justice and food democracy. While Brazil has privileged the production and export of agricultural commodities, heterogeneity is still a main attribute of the contemporary Brazilian agrifood system, and it needs to be more carefully analyzed.

Publisher's Note Springer Nature remains neutral with regard to jurisdictional claims in published maps and institutional affiliations. 